\title{
Antigenic Relationships \\ Among Strains of Mycoplasma mycoides var. mycoides, M. capri and $M$. laidlawii Revealed by Complement-fixation Tests
}

\author{
By R. M. GRIFFIN* \\ Federal Department of Veterinary Research, Vom, Nigeria
}

(Accepted for publication 26 March 1969 )

SUMMARY

\begin{abstract}
Complement-fixation tests were used to compare strains of Mycoplasma mycoides var. mycoides (5 strains), $M$. mycoides var. capri (5 strains) and $M$. laidlawii of bovine genital origin (3 strains). Strains of $M$. mycoides and $M$. capri showed cross-reactions of about $25 \%$ identity, but strains of $M$. laidlawii appeared to be antigenically distinct. The results, measured in terms of the amounts of complement fixed, are shown graphically and discussed in relation to the diagnosis of contagious bovine pleuropneumonia.
\end{abstract}

\section{INTRODUCTION}

The clinical diagnosis of contagious bovine pleuropneumonia (CBPP) presents many difficulties because of the occurrence within a herd of atypical cases, subclinical infections and apparently recovered animals which may harbour viable organisms within sequestra in the lungs. Serological tests have been developed to aid diagnosis, notably techniques of agglutination, precipitation, complement-fixation (CF) and allergic skin tests. All have had variable success; none entirely meets the ideal diagnostic requirements of specificity, reliability and ease of use (Gourlay, 1965; Griffin, 1967). The main diagnostic problem remains the recognition of the 'carrier' animal in which the titre of circulating antibody is below the thresholds detectable by existing serological tests. Complement-fixation tests have, in general, been chosen for the examination of sera from individual animals because experience has shown that positive reactions may be expected from the sera of a greater proportion of cattle at different stages of infection than by the use of any other single test. The value of agglutination tests, which for field diagnosis are easier to use, has been limited by lack of specificity and sensitivity manifest in the occurrence of both positive and negative false reactions (Ito, Yamagiwa \& Itabashi, 1931; Campbell, 1938; Turner, 1962). An explanation for false negative reactions postulated by Turner was the neutralization in vivo of circulating antibody following the release of specific mycoplasma antigen into the circulation, possibly during a septicaemic phase of acute infection. Adler \& Etheridge (1964) failed to improve the sensitivity of the test by modification of the method of preparation of the agglutinating suspension. A suggested explanation for false positive reactions is the occurrence of antigens common to Mycoplasma mycoides var. mycoides (M. mycoides) and other mycoplasma species

* Present Address: Veterinary Research Laboratories, May and Baker Limited, Ongar, Essex. 
or other micro-organisms. The results of CF tests among strains of $M$. mycoides, $M$. mycoides var. capri (M. capri) and $M$. laidlawii of bovine genital origin are now reported.

\section{METHODS}

\section{Complement fixation}

A plate complement-fixation (CF) test was used, based on that described by Fulton \& Dumbell (1949) in which data obtained from preliminary assays of the reagents were used to establish a comparative test. Differences only from this technique are described.

Test plates. Standard (WHO pattern) plastic haemagglutination plates were used. They were stored in air-tight tins made to hold six plates. The lids of the tins were lined with absorbent paper pads, moistened to maintain a humid atmosphere around the plates during incubation.

Pipettes. Dropping pipettes to deliver $50 \mathrm{drops} / \mathrm{ml}$. were used. Standard graduated glass delivery-pipettes were used to prepare dilutions of all reagents. An automatic syringe of $2.0 \mathrm{ml}$. capacity calibrated in $0.1 \mathrm{ml}$. intervals (Bradstreet \& Taylor, 1962) was used for the multiple distribution of volumes of reagents.

Glassware for CF tests was not used for other purposes and together with the plastic test plates was washed following the procedure described by Bradstreet \& Taylor (1962).

Diluent. Dilutions of the test reagents were prepared in veronal $+\mathrm{NaCl}$ buffer ( $\mathrm{pH} \mathrm{7 \cdot 3)} \mathrm{made} \mathrm{up} \mathrm{in} \mathrm{glass-distilled} \mathrm{de-ionized} \mathrm{water.}$

Sensitized sheep erythrocytes. Blood was collected from locally bred sheep kept at the laboratory. With aseptic technique and sterile materials, Ioo ml. blood was bled from the jugular vein into $50 \mathrm{ml}$. modified Alsever solution, thoroughly mixed and allowed to stabilize at $4^{\circ}$ for 4 days before use. Thereafter, the blood was stored at $4^{\circ}$ up to 28 days provided no discolouration, haemolysis or difficulty in resuspension of the cells after centrifugation during washing was encountered.

A I $\%(w / v)$ suspension of red cells was sensitized by incubation at $37^{\circ}$ for $\mathrm{I} \mathrm{hr}$ with an equal volume of horse anti-sheep haemolysin (Burroughs Wellcome Ltd.). A concentration of 4 times the minimal haemolytic dose was used as the optimal sensitizing concentration of haemolysin. This was determined in a preliminary twodimensional assay of dilutions of haemolysin and guinea-pig complement.

Complement. Guinea-pig serum for complement was collected, pooled, lyophilized in $2.0 \mathrm{ml}$. volumes and stored at $-20^{\circ}$. Ampoules of pooled serum were reconstituted in cooled distilled water and dilutions were made in cooled diluent.

Storage of guinea-pig serum at $4^{\circ}$ by Richardson's (I94I) method was also tried, but the activity fell appreciably in 6 weeks under conditions in Vom, Nigeria, whereas the lyophilized preparations retained full activity for at least 6 months.

The complement unit, defined as that amount of complement in the highest dilution of guinea-pig serum which produces $50 \%$ haemolysis of an optimally sensitized sheep-cell suspension, was also determined in the preliminary assay between dilutions of guinea-pig serum and dilutions of haemolysin. 


\section{Strains of mycoplasma}

The strains used and their origins are listed in Table $\mathrm{r}$; all were preserved at $-20^{\circ}$, both frozen in broth culture and lyophilized. The virulence of strains of Mycoplasma mycoides, with the exception of strain $\mathrm{KH}_{3} / \mathrm{J}$, was confirmed by the subcutaneous inoculation of fresh broth culture into susceptible Zebu bulls. The virulence of strains of $M$. capri was confirmed similarly by subcutaneous inoculation in susceptible goats.

\section{Table I. Mycoplasma strains}

\begin{tabular}{|c|c|c|}
\hline Species & Strain & Origin \\
\hline \multirow[t]{5}{*}{$\begin{array}{l}\text { Mycoplasma mycoides } \\
\text { var. mycoides. }\end{array}$} & $\mathrm{KH} \mathrm{3/s}$ & $\begin{array}{l}\text { Obtained from Khartoum about } 1954 \text {-preserved } \\
\text { lyophilized in Vom at } 83 \text { rd broth-culture } \\
\text { passage-avirulent for local cattle }\end{array}$ \\
\hline & MAIDUGURI 8 (M. 8) & $\begin{array}{l}\text { Isolated in } 196 \mathrm{I} \text { in Vom from pneumonic lung } \\
\text { received from Bornu Province }\end{array}$ \\
\hline & ZAGO & $\begin{array}{l}\text { Isolated in } 1963 \text { in Vom from pneumonic lung } \\
\text { from a natural case of CBPP in Kano Province }\end{array}$ \\
\hline & GLADYSDALE (GLAD) & $\begin{array}{l}\text { Isolated in Australia in } 1953 \text { and stored in frozen } \\
\text { tissue-imported in broth culture into Nigeria } \\
\text { in } 196 \mathrm{I}\end{array}$ \\
\hline & VICTORIA 5 (v. 5) & $\begin{array}{l}\text { Isolated in Australia in } 1936 \text {. From Ioth broth- } \\
\text { culture passage, it has been used as a vaccine. } \\
\text { Received in Nigeria in } 1962 \text { at } 2 \text { Ist broth- } \\
\text { culture passage-virulent for local cattle }\end{array}$ \\
\hline \multirow[t]{5}{*}{ M. mycoides var. capri } & $N / 108$ & $\begin{array}{l}\text { Isolated about } 1950 \text { from pneumonic goat lung } \\
\text { from Benin. Preserved lyophilized at } 77 \text { th broth- } \\
\text { culture passage-virulent for goats. Believed to } \\
\text { be the original strain of Longley (195I) }\end{array}$ \\
\hline & GOAT 8 (G. 8) & $\begin{array}{l}\text { Isolated in } 1956 \text { from pneumonic goat lung from } \\
\text { Benin-remains virulent for goats }\end{array}$ \\
\hline & voм. I & $\begin{array}{l}\text { Isolated in } 1962 \text { from pneumonic goat lung from } \\
\text { Kano province }\end{array}$ \\
\hline & KADUNA I (KAD. I) & Isolated in 1962 from tissue from Kaduna \\
\hline & Strain 28 (s. 28) & $\begin{array}{l}\text { Isolated about } 1956 \text { from pneumonic goat lung } \\
\text { tissue received from Benin }\end{array}$ \\
\hline M. laidlawii & $\begin{array}{l}\text { Strain } 35 \\
\text { Strain XI } \\
\text { Strain XII }\end{array}$ & $\begin{array}{l}\text { Obtained in } 1962 \text { as lyophilized cultures from } \\
\text { Farcha Laboratory, Republic of Tchad, through } \\
\text { the courtesy of Dr A. Provost (Villemot \& } \\
\text { Provost, I959a) }\end{array}$ \\
\hline
\end{tabular}

\section{Antigens}

Antigen suspensions of each strain were prepared from ox serum enriched broth cultures as described by Griffin (1964), using a frozen culture as seed. The cultures were centrifuged in a Sharples continuous-flow centrifuge and the organisms harvested

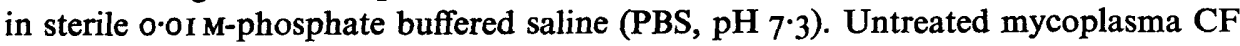
antigen suspensions (Card, 1959) were used throughout. The crude suspensions were ground in Griffith tubes, washed and resuspended at $\mathrm{I} / \mathrm{ro}$ dilution and stored at $4^{\circ}$ with thiomersalate $(\mathrm{I} / \mathrm{I} 0,000)$ as a preservative. 


\section{Antisera}

Anti-mycoplasma sera were prepared in New Zealand white rabbits of about $2 \mathrm{~kg}$. bodyweight as described by Griffin (1964). Intravenous injections were used of increasing volumes of washed antigen suspension diluted in PBS to a density equivalent to Brown's opacity tube No. 3 (Burroughs Wellcome). All sera were inactivated at I/ 10 dilution by heating for $30 \mathrm{~min}$. in a $56^{\circ}$ water bath. Natural haemolysins against sheep red cells were removed by absorbing the sera with sheep red cell stromata. The stromata were prepared by lysing a volume of red cells packed by centrifugation at $1000 \mathrm{~g}$ for $20 \mathrm{~min}$. with an equal volume of distilled water, followed by freezing and thawing once. The stromata were washed three times in diluent, resuspended to their original volume and stored at $-20^{\circ}$. One volume of stromata was mixed with two volumes of rabbit antiserum at $1 / 10$ dilution and the mixture incubated in a water bath at $37^{\circ}$ for $20 \mathrm{~min}$. The mixture was centrifuged, the absorbed serum decanted and the absorption process repeated.

Antisera were stored at $-20^{\circ}$ and working sets in $5^{\circ} \mathrm{O} \mathrm{ml}$. volumes to which thiomersalate $(\mathrm{I} / \mathrm{IO}, 000)$ was added were dispensed and stored at $4^{\circ}$. Antisera against $\mathrm{Myco}-$ plasma mycoides strain $\mathrm{KH} 3 / \mathrm{J}, M$. capri strain N.I08 and $M$. laidlawii strain 35 were designated as representative sera for their particular species.

\section{General procedures for CF tests}

Antigen standardization. The object of this assay was to select a routine test dilution of each antigen suspension which in the presence of a I/IO dilution of an homologous antiserum would fix an arbitrarily chosen amount of complement ( $\mathrm{I} \cdot \mathrm{O} \log$.-units) under the test conditions. Two-dimensional assays were made in which dilutions of each antigen were titrated against dilutions of guinea-pig serum in the presence of a $\mathrm{I} / \mathrm{IO}$ dilution of homologous serum as the constant test component.

Comparison of complement-fixing antigens. The routine test dilution of each mycoplasma antigen, in the presence of dilutions of an homologous or heterologous rabbit anti-mycoplasma serum and dilutions of guinea-pig serum was tested for complement fixation. Strains of each species were examined for antigenic homogeneity before the cross-reactions between species were investigated.

Two-dimensional assays were used throughout in which a log. $0 \cdot 3$ dilution series of each representative antiserum was tested against a log. $0 \cdot 2$ dilution series of guinea-pig serum in the presence of antigen suspension dispensed at the routine test dilution as the constant test component. Two plates were used for each titration; on plate I a complete test was done and on plate 2 , a serum control plate, the antigen was replaced by unit volume $(0.02 \mathrm{ml}$.) of diluent. A linear complement titration without antigen was included as a control for pro- or anti-complementary activity of the antigen suspension.

The log.-units of complement fixed specifically by each antigen were calculated from the differences in the fixation obtained between corresponding rows in the full test (plate I) and the antiserum control plate (plate 2). Graphs of the complement fixed (log.-units) by the routine test dilution of each antigen suspension in the presence of antiserum were plotted on graph paper. The areas beneath the curves, which represented the complement fixed, were used as a basis for comparison of the antigens. Areas were measured as described by Kraft \& Melnick (1950) with a compensating polar plani- 
meter (A. Ott, Kemten, Bayern, West Germany). This method gave the same results as the method of weighing described by Fulton \& Dumbell (1949).

\section{RESULTS}

Determination of the minimal haemolytic dose of haemolysin and the complement unit

The results of a typical assay are shown in Fig. I, in which the complement unit was defined in a log. 2.o dilution of guinea-pig serum. The minimal haemolytic dose of haemolysin was observed at $\log .2 \cdot 7$ dilution of the horse anti-sheep red cell serum from which the optimal sensitizing concentration was calculated as log. 2.I dilution of the particular serum.

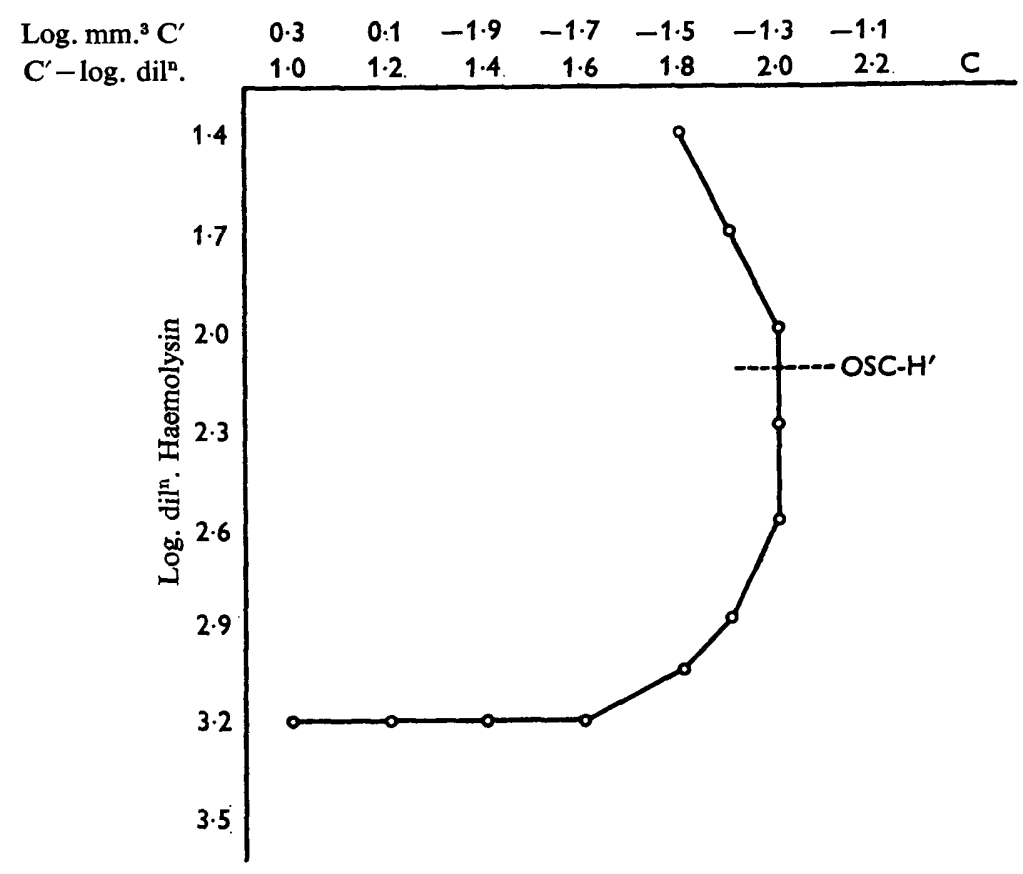

Fig. 1. Plate titration between dilutions of horse anti-sheep haemolysin and dilutions of guinea-pig serum to determine the optimal sensitizing concentration of haemolysin $\left(\mathrm{OSC}-\mathrm{H}^{\prime}\right)$.

\section{Standardization of antigens}

The results of an assay of Mycoplasma mycoides strain $\mathrm{KH} 3 / \mathrm{J}$ antigen are given in Table 2, and the results for all strains are summarized in Table 3 and shown in Fig. 2 3, 4, from which the test dilutions of each suspension which fixed $\mathrm{I} \cdot 0$ log.-units $\left(0 \cdot 2 \mathrm{~mm}^{3}\right)$ of complement were determined.

Relationship between strains within each species

The results of titrations of dilutions of each representative antiserum and dilutions of guinea-pig serum in the presence of the test dilution of each antigen suspension of the homologous species are shown in Fig. 5, 6, 7. The areas beneath each curve 
expressed as fractions of the area obtained in the homologous sets $(=\mathrm{I} \cdot 0)$, which enabled direct comparison of the amounts of complement fixed to be made, are shown in Table 4. The results show that strains within each species group were not identical, since reciprocal cross-reactions were not observed. However, within each group substantial cross-reactions did occur, which suggests that the strains are similar antigenically. Mycoplasma mycoides strain ZAGo fixed less complement with the representative antiserum, which suggests it was antigenically weak.

Table 2. Complement fixation of Mycoplasma mycoides strain $\mathrm{KH} / \mathrm{f}$ antigen against an homologous rabbit antiserum at $\mathrm{I} / \mathrm{IO}$ dilution. Calculation of the amount of complement $\left(C^{\prime}\right)$ fixed

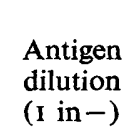

\begin{tabular}{|cc} 
Complement fixed $\left(\mathrm{mm}^{3} \mathrm{C}^{\prime}\right)$ \\
antigen + & \\
5.00 & Antigen \\
5.00 & 0.80 \\
5.00 & 0.80 \\
5.00 & 0.32 \\
3.40 & 0.32 \\
2.00 & 0.20 \\
1.00 & 0.20 \\
0.60 & 0.20 \\
0.20 & 0.20 \\
0.15 & 0.20
\end{tabular}

* Antigen dilution replaced by a volume of diluent.

$\begin{array}{cc}\mathrm{mm} .^{3} \mathrm{C}^{\prime} & \begin{array}{c}\log _{10} \\ \left(\mathrm{~mm}^{3}{ }^{3} \mathrm{C}^{\prime}\right)\end{array} \\ 4 \cdot 20 & 0.62 \\ 4 \cdot 20 & 0.62 \\ 4.68 & 0.67 \\ 4.68 & 0.67 \\ 3 \cdot 20 & 0.5 \mathrm{I} \\ \mathrm{I} \cdot 80 & 0.25 \\ 0.80 & \mathrm{I} \cdot 90 \\ 0.40 & \mathrm{I} \cdot 60 \\ 0 & 0 \\ 0 & 0\end{array}$

Table 3. Complement fixed $\left(\log . \mathrm{mm} .^{3}\right)$ by dilutions of Mycoplasma antigens in the presence of homologous rabbit antisera at I/IO dilution

\begin{tabular}{|c|c|c|c|c|c|c|c|c|c|c|c|c|c|}
\hline \multirow{3}{*}{$\begin{array}{l}\text { Anti- } \\
\text { gen } \\
\text { dilu- } \\
\text { tion }\end{array}$} & \multicolumn{13}{|c|}{ Complement fixed (log. $\left.\mathrm{mm} .^{8}\right)$} \\
\hline & \multicolumn{5}{|c|}{ M. mycoides strains } & \multicolumn{5}{|c|}{ M. capri strains } & \multicolumn{3}{|c|}{ M. laidlawii strain } \\
\hline & $\mathbf{K H ~ 3 / J ~}$ & $v / 5$ & GLAD. & M. 8 & ZAGO & $\mathrm{N} / 108$ & G. 8 & VOM I & s. 28 & KAD. I & 35 & XI & XII \\
\hline 2 & 0.62 & 0.62 & 0.57 & 0.65 & 0.62 & 0.57 & 0.65 & 0.65 & 0.62 & 0.62 & 0.62 & 0.62 & 0.62 \\
\hline 4 & 0.62 & 0.65 & 0.57 & 0.65 & 0.62 & 0.57 & 0.65 & 0.65 & 0.62 & 0.62 & 0.62 & 0.62 & 0.65 \\
\hline 8 & 0.67 & 0.65 & 0.57 & 0.65 & 0.43 & 0.57 & 0.54 & 0.57 & 0.62 & 0.62 & 0.62 & 0.62 & 0.6 \\
\hline I6 & 0.67 & 0.54 & 0.57 & 0.65 & $0 \cdot 18$ & 0.57 & 0.54 & 0.46 & 0.50 & 0.50 & 0.50 & 0.43 & 0.4 \\
\hline 32 & $0.5 \mathrm{I}$ & 0.43 & 0.43 & 0.54 & 0.18 & 0.29 & 0.43 & 0.23 & 0.08 & 0.08 & 0.08 & 0.20 & 0.2 \\
\hline 64 & 0.25 & 0.30 & 0.29 & $0.4 \mathrm{I}$ & 0.02 & $\bar{I} \cdot 87$ & $\bar{I} \cdot 70$ & $\bar{I} \cdot 97$ & $\bar{I} \cdot 87$ & $\mathrm{I} \cdot 67$ & $\overline{\mathrm{I}} \cdot 87$ & $\overline{\mathrm{I}} \cdot 97$ & $\bar{I} \cdot 98$ \\
\hline 128 & $\vec{I} \cdot 90$ & $\mathrm{I} \cdot 48$ & $\bar{I} \cdot 87$ & $\bar{I} \cdot 70$ & $\bar{I} \cdot 88$ & $\bar{I} \cdot 70$ & $\bar{I} \cdot 48$ & $\mathrm{I} \cdot 68$ & $\bar{I} \cdot 67$ & $\bar{I} \cdot 60$ & $\bar{I} \cdot 66$ & $\bar{I} \cdot 88$ & $\mathrm{I} \cdot 88$ \\
\hline 256 & $\mathrm{I} \cdot 60$ & 0 & $\bar{I} \cdot 38$ & $\mathrm{I} \cdot 48$ & $\mathrm{I} \cdot 48$ & 0 & 0 & $I \cdot 26$ & 0 & 0 & $\bar{I} \cdot 30$ & $\mathrm{I} \cdot 64$ & $\mathrm{I} \cdot 70$ \\
\hline
\end{tabular}

Relationship between strains of heterologous species

Titrations were made between dilutions of the representative antisera and dilutions of guinea-pig serum in the presence of the test dilutions of each heterologous antigen suspension. The log.-units of complement fixed specifically in each heterologous antigenantibody reaction were calculated and the results shown graphically (Fig. 8, 9). Areas representing specific complement fixation expressed as fractions of the areas obtained in homologous antigen-antibody sets are included in Table 4.

Cross-reactions of about $25 \%$ identity were observed in tests between Mycoplasma mycoides and M. capri. Mycoplasma laidlawii was judged to be distinct antigenically, 


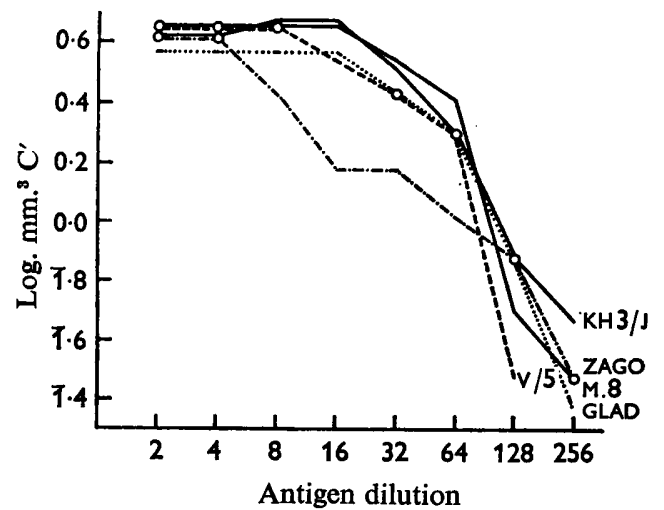

Fig. 2

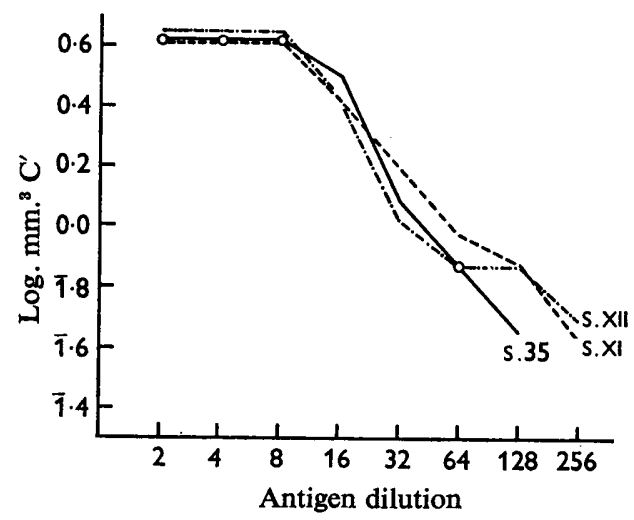

Fig. 4

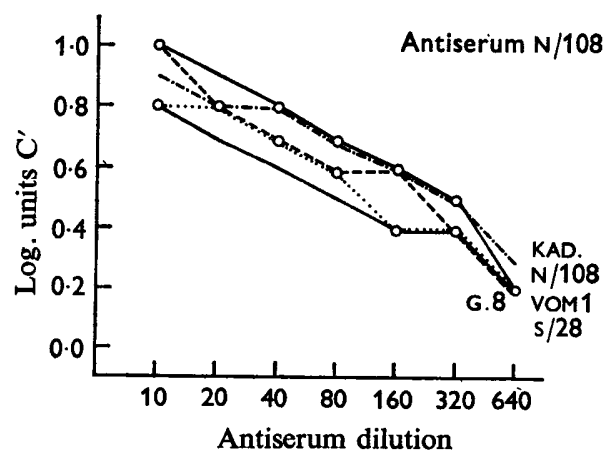

Fig. 6

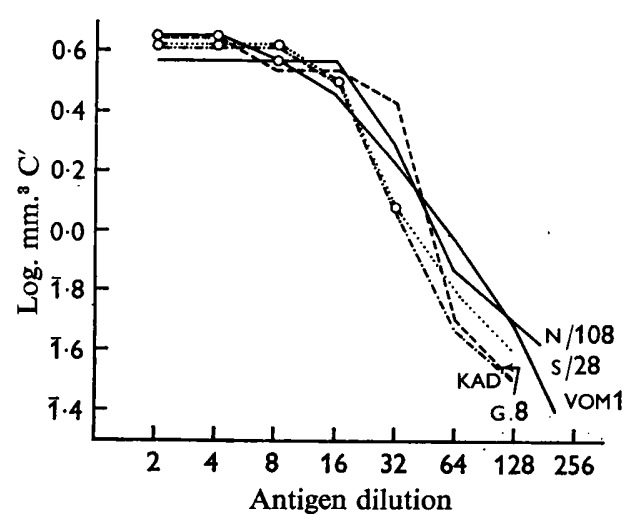

Fig. 3

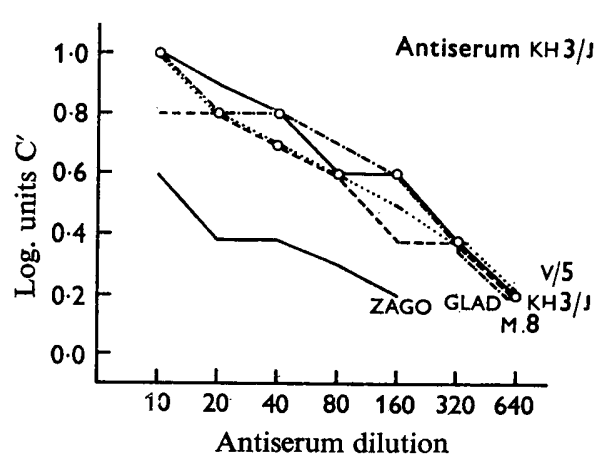

Fig. 5

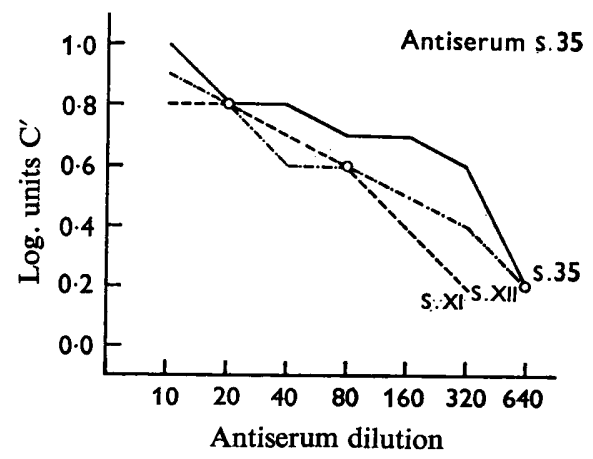

Fig. 7

Fig. 2, 3, 4. Antigen standardization. Complement fixed by dilutions of fresh mycoplasma antigens in the presence of homologous rabbit antisera at $1 / 10$ dilution. Fig. 2. M. mycoides antigen suspensions. Fig. 3. $M$. capri antigen suspensions. Fig. 4. M. laidlawii antigen suspensions.

Fig. 5, 6, 7. Complement fixed by fresh mycoplasma antigens when titrated against representative antisera of the homologous species. Fig. 5. M. mycoides systems. Fig. 6. $M$. capri systems. Fig. 7. M. laidlawii systems. 


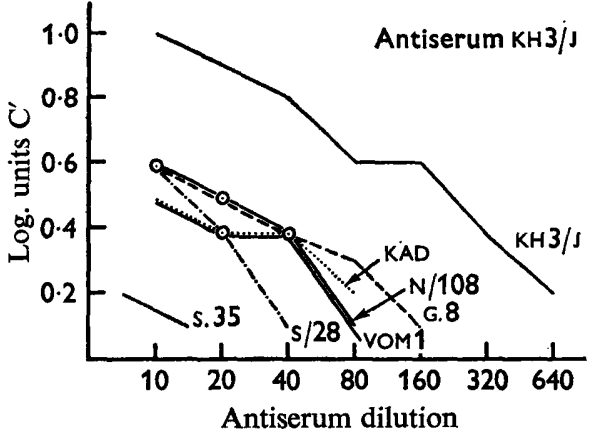

Fig. 8

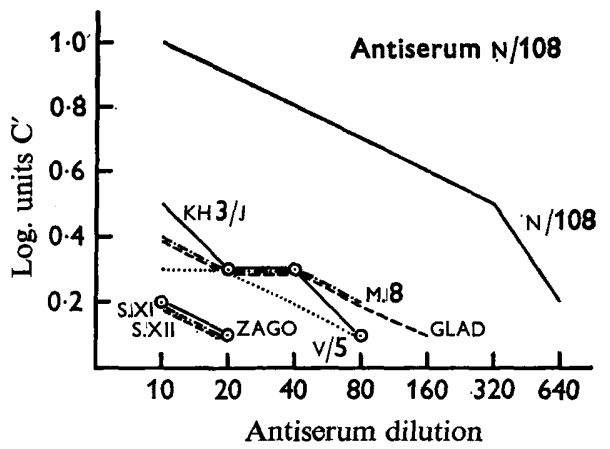

Fig. 9

Fig. 8, 9. Complement fixed by fresh mycoplasma antigens titrated against representative antisera of the heterologous species.

Table 4. Synoptic table of the antigenic relationships among strains of Mycoplasma mycoides, $M$. capri and $M$. laidlawii determined by complement fixation

\begin{tabular}{|c|c|c|c|c|c|c|c|c|c|}
\hline \multirow[b]{3}{*}{ Antigen } & \multicolumn{9}{|c|}{ Antiserum } \\
\hline & \multicolumn{3}{|c|}{ M. mycoides } & \multicolumn{3}{|c|}{ M. capri } & \multicolumn{3}{|c|}{ M. laidlawii } \\
\hline & KH 3/J & $v / 5$ & M. 8 & $\mathrm{~N} / \mathrm{I} 08$ & VOM I & KAD. I & 35 & $\mathbf{X I}$ & XII \\
\hline \multicolumn{10}{|c|}{ M. mycoides } \\
\hline KH 3/J & $1 \cdot \infty 0^{*}$ & 0.72 & 0.88 & 0.22 & 0.24 & $0 \cdot 10$ & 0.007 & 0 & 0 \\
\hline$v / 5$ & 0.88 & $1 \cdot 00$ & 0.81 & $0 \cdot 12$ & $0.2 \mathrm{I}$ & 0.21 & 0.014 & 0 & 0 \\
\hline M. 8 & 0.99 & 0.78 & $1 \cdot 00$ & $0 \cdot 18$ & $0 \cdot 27$ & 0.21 & 0.007 & 0 & 0 \\
\hline GLAD. & 0.79 & 0.71 & 0.88 & 0.19 & 0.24 & $0 \cdot 10$ & 0 & 0 & 0 \\
\hline ZAGO & 0.24 & 0.28 & 0.40 & 0.015 & 0.05 & 0.07 & 0 & 0 & 0 \\
\hline \multicolumn{10}{|l|}{ M. capri } \\
\hline $\mathrm{N} / 108$ & 0.28 & 0.23 & 0.19 & $1 \cdot 00$ & 0.71 & 0.69 & 0 & 0 & 0 \\
\hline VOM I & 0.25 & 0.24 & 0.12 & $1 \cdot 00$ & $1 \cdot 00$ & 0.72 & 0 & 0 & 0 \\
\hline KAD. I & 0.23 & 0.14 & 0.16 & 0.82 & 0.77 & $1 \cdot 00$ & 0 & 0 & 0 \\
\hline G. 8 & 0.38 & 0.34 & 0.13 & 0.92 & 0.86 & 0.66 & 0 & 0 & 0 \\
\hline s. 28 & 0.17 & 0.18 & 0.13 & 0.67 & 0.85 & $1 \cdot 00$ & 0 & 0 & 0 \\
\hline \multicolumn{10}{|c|}{ M. laidlawii } \\
\hline 35 & 0.015 & 0 & 0 & 0 & 0 & 0 & $1 \cdot 00$ & 0.46 & 0.83 \\
\hline $\mathbf{X I}$ & 0 & 0.06 & 0 & 0.015 & 0 & 0.007 & 0.77 & $I \cdot 00$ & 0.93 \\
\hline XII & 0 & 0.03 & 0 & 0.015 & 0 & 0.04 & 0.79 & 0.83 & $1 \cdot 00$ \\
\hline
\end{tabular}

* Areas representing specific fixation expressed as proportions of those obtained in homologous antigen-antibody sets (homologous $=\mathrm{I} \cdot 00)$.

despite small and irregular cross-reactions with certain strains of $M$. mycoides and $M$. capri. Since reciprocal cross-reactions were not observed, the relationships between $M$. mycoides and $M$. capri have been expressed as the arithmetic means of the complement fixation observed in each complete antigen-antibody set. These results (Table 5) show the size and regularity of the cross-reactions among strains of these species. 
Table 5. Relationship among complement-fixing antigens of strains of Mycoplasma mycoides, $M$. capri and $M$. laidlawii. Arithmetic means of the amounts of complement fixed in complete antigen-antibody sets

\begin{tabular}{|c|c|c|c|c|c|c|c|c|c|}
\hline & \multicolumn{9}{|c|}{ Antiserum } \\
\hline & \multicolumn{3}{|c|}{ M. mycoides } & \multicolumn{3}{|c|}{ M. capri } & \multicolumn{3}{|c|}{ M. laidlawii } \\
\hline & $\mathrm{KH} 3 / \mathbf{J}$ & $v / 5$ & M. 8 & $\mathrm{~N} / \mathrm{I08}$ & VOM I & KAD. I & 35 & XI & XII \\
\hline \multicolumn{10}{|c|}{ M. mycoides } \\
\hline KH $3 / \mathbf{J}$ & $1 \cdot 00 *$ & 0.80 & 0.94 & 0.25 & 0.25 & 0.17 & 0.01 & 0 & 0 \\
\hline$v / 5$ & - & $\mathbf{I} \cdot \infty$ & 0.80 & 0.19 & 0.20 & $0 \cdot 18$ & 0.004 & 0 & 0 \\
\hline M. 8 & - & - & $\mathbf{I} \cdot \infty$ & 0.18 & 0.28 & 0.18 & 0.007 & 0.03 & 0.02 \\
\hline \multicolumn{10}{|l|}{ M. capri } \\
\hline $\mathrm{N} / 108$ & - & - & - & I $\cdot 00$ & 0.85 & $0 \cdot 76$ & 0 & 0.007 & 0.007 \\
\hline VOM I & - & - & - & - & $1 \cdot 00$ & 0.75 & 0 & 0 & 0 \\
\hline KAD. I & - & - & 一 & - & - & $1 \cdot 00$ & 0 & 0.004 & 0.12 \\
\hline \multicolumn{10}{|c|}{ M. laidlawii } \\
\hline 35 & - & - & - & - & - & - & $1 \cdot 00$ & 0.62 & $0.8 \mathrm{I}$ \\
\hline XI & - & - & - & - & - & - & - & $1 \cdot 00$ & 0.89 \\
\hline XII & - & 一 & - & - & - & - & - & - & $1 \cdot 00$ \\
\hline
\end{tabular}

\section{DISCUSSION}

Mycoplasma laidlawii has been isolated from the bovine genital tract (Edward, Hancock \& Hignett, 1947; Villemot \& Provost, I959a) and from the bovine respiratory tract (Harbourne, Hunter \& Leach, 1965) but its significance is not well understood. Furthermore, because this organism had been shown to be related serologically by both agglutination and precipitation tests to M. mycoides (Provost \& Villemot, 1959) and to be antigenic for cattle, its possible immunogenicity against contagious bovine pleuropneumonia (CBPP) was suggested (Provost, I960) although subsequent experiments did not confirm this suggestion (Provost, Villemot \& Queval, 1964).

Strains of Mycoplasma capri, likewise, related serologically to $M$. mycoides (Provost \& Villemot, 1959; Villemot \& Provost, I959 $b$ ) and antigenic for cattle did not protect cattle against CBPP (R. M. Griffin, unpublished data). Hudson (1964), in Australia, also failed in attempts to protect cattle against CBPP with the Y strain of mycoplasma isolated from a goat and related serologically by CF tests to M. mycoides (Laws, 1956). Mycoplasma capri does not appear to be a naturally occurring pathogen for cattle, although the pathogenicity of strains experimentally have been reported (Heikkilä, 1956; Provost \& Villemot, 1959). Opportunities among cattle for transmission of micro-organisms by the respiratory route are frequent because among nomadic cattle-owners in Northern Nigeria it is the practice to graze and kraal together cattle, sheep and goats. It seemed, therefore, among those mycoplasmas which might stimulate in cattle the production of antibodies which cross-react with $M$. mycoides, thereby interfering with the response to serodiagnostic tests for CBPP, that $M$. capri and $M$. laidlawii should first be investigated.

Among the problems found with complement-fixation (CF) techniques for CBPP diagnosis (reviewed by Griffin, 1967), the main difficulty appears to have been the preparation of suitable antigens. The heat-treated, matured suspension of Campbell \& Turner (I953) has been preferred generally, but in comparative tests among the 
Mycoplasmataceae fresh suspensions have been used recently (Hudson, Cottew \& Adler, 1967). Little pro- or anti-complementary activity was found with these suspensions by Stokes (1955); Card (1959) found no difference in potency between fresh and heat-treated antigen suspensions from mycoplasmas of human origin; furthermore, the maturation process did not increase the CF potency.

Comparative CF tests among Mycoplasma mycoides, $M$. capri and $M$. laidlawii have given conflicting results. The relationship between $M$. mycoides and $M$. capri was studied by Provost, Villemot, Queval \& Borredon (I964) and by Lemcke (I964). They reported results similar to those in the present study, namely, that cross-reactions of about $25 \%$ identity were observed. Lemcke found the strains of $M$. capri G I/6I, G.II isolated by Pillai from goats with pleuropneumonia in the Sudan indistinguishable from $M$. mycoides-a result confirmed with strain G I/6I in Australia by Hudson \& Cottew (cited by Lemcke, 1964). By contrast, failure to demonstrate a relationship between $M$. capri and $M$. mycoides was reported by Loizelier (1950) and Edward \& Leach (1964), who found also that $M$. laidlawii was antigenically distinct.

The relationship between Mycoplasma mycoides and strains of $M$. laidlawii of human origin was investigated by Card (I959), who, in linear CF tests between antigen-antibody sets, found a slight cross-reaction. Provost, Villemot, Queval \& Borredon (I964), with bovine genital isolates of $M$. laidlawii and antisera prepared in donkeys, obtained results similar to those of Card. They reported also a close relationship between $M$. laidlawii and $M$. capri, a result which conflicts not only with those of the present study in which some of Provost's strains were used, but also with the results of Edward \& Leach (1964).

It seems likely that these anomalous results are caused by differences in the cultural methods, antiserum preparation or CF techniques used. Antisera prepared in different hosts and by the use of different injection schedules may stimulate different responses to particular antigens, which may be detected by CF tests. It is difficult to compare the degrees of sensitivity of the many CF techniques which have been used. A refinement which might be applied to comparisons of the amounts of complement fixed would be to define from the complement unit the smallest detectable amount of complement. This could then be used as a base line for graphs used for the measurement of the areas of fixation. Conclusions about these antigenic relationships must await the results of tests with more strains made under standard conditions. However, the antigenic cross-reactions revealed between the strains of Mycoplasma mycoides and $M$. capri suggest that this latter organism may be a cause of non-specific positive results in serodiagnostic tests for contagious bovine pleuropneumonia. This postulated relationship needs further field investigation and its significance must be evaluated in the wider context of antigenic cross-reactions among $M$. mycoides, other mycoplasmas, bacteria and polysaccharides from other sources reported recently (Gourlay \& Shifrine, 1966; Shifrine \& Gourlay, 1967).

My thanks are due to Professor Forrest Fulton for his interest in the work and criticism of this manuscript. The paper is based on part of a Ph.D. thesis accepted by the University of London. 


\section{REFERENCES}

Adler, H. E. \& Ethermge, J. R. (1964). Contagious bovine pleuropneumonia: A comparison of two slide agglutination blood tests with the complement-fixation test. Aust. vet J. 40, 38 .

Bradstreet, P. C. M. \& TAYLOR, C. E. D. (1962). Techniques of complement-fixation test applicable to the diagnosis of virus diseases. Mon. Bull. Minist. Hlth 2r, 96.

Campbell, A. D. (1938). Contagious bovine pleuropneumonia. A report on the use of new antigens for the complement-fixation and agglutination test. J. Coun. scient. ind. Res. Aust. II, I I 2.

Campbell, A. D. \& TuRner, A. W. (1953). Studies on contagious pleuropnoumonia of cattle. IV. An improved complement-fixation test. Aust. vet. J. 29, 154.

CARD, D. H. (1959). PPLO of human genital origin. Serological classification of strains and antibody distribution in man. Br. J. vener. Dis. 35, 27.

Edward, D. G. ff. \& LeACH, R. H. (1964). Rep. 2nd Meeting. Joint FAO/OIE/CCTA Expert Panel on contagious bovine pleuropneumonia, Muguga, Kenya.

EdWARD, D. G. ff., Hancock, J. L. \& HigneTt, S. L. (I947). Isolation of pleuropneumonia-like organisms from the bovine genital tract. Vet. Rec. 59, 329.

Fulton, F. \& Dumbell, K. R. (1949). The serological comparison of strains of influenza virus. J. gen. Microbiol. 3, 97 .

Gourlay, R. N. (I965). Comparison between some diagnostic tests for contagious bovine pleuropneumonia. J. comp. Path. Ther. 75, 97.

Gourlay, R. N. \& Shifrine, M. (1966). Antigenic cross reactions between the galactan from $M y c o-$ plasma mycoides and polysaccharides from other sources. J. comp. Path. Ther. 75, $4 \mathrm{I} 7$.

GrIFFIN, R. M. (1964). A gel diffusion precipitin test for contagious bovine pleuropneumonia. J. comp. Path. Ther. 75, 223.

GRIFFIN, R. M. (1967). Studies of the serological reactions of some species of the Mycoplasmataceae with particular reference to the diagnosis of contagious bovine pleuropneumonia. Ph.D. Thesis, University of London.

Harbourne, J. F., Hunter, D. \& Leach, R. H. (1965). The isolation of mycoplasma from bovine lungs and nasal swabs. Res. vet. Sci. 6, 178.

HeIkxILÄ, I. (1965). Pleuropneumonia infections of sheep. Bull. Off. int. Epizoot. 46, 586.

Hudson, J. R. (1964). Contagious bovine pleuropneumonia-Laboratory work in relation to the eradication campaign. Aust. vet. J. 40, 95.

Hudson, J. R., Cottew, G. S. \& Adler, H. E. (1967). Diseases of goats caused by mycoplasma: A review of the subject with some new findings. Ann. N.Y. Acad. Sci. 143, 287.

Ito, S., Yamagrwa, S. \& Itabashi, K. (I93I). Comparative studies among complement-fixation test, agglutination, precipitogen, precipitin reactions for the diagnosis of contagious bovine pleuropneumonia. J. Jap. Soc. vet. Sci. ro, 100.

Kraft, L. M. \& MeLnick, J. L. (1950). Immunological reactions of the Coxsackie viruses, II. The complement-fixation test. J. exp. Med. 92, 483 .

LAws, L. (1956). A pleuropneumonia-like organism causing peritonitis in goats. Aust. vet. J. 32, 326.

LEMCKE, R. M. (1964). The serological differentiation of mycoplasma strains (pleuropneumonia-like organisms) from various sources. J. Hyg., Camb. 62, 199.

Loizelier, A. B. (1950). Caprine infectious pleuropneumonia in Spain. Trab. Inst. Biol. anim., Madr. 9, 323.

LONGLEY, E. O. (195I). Contagious caprine pleuropneumonia. A study of the disease in Nigeria. Colon. Res. Publs No. 7, H.M.S.O., London.

Provost, A. (1960). Rep. Ist Meeting, Joint FAO/OIE/CCTA Expert Panel on contagious bovine pleuropneumonia, Melbourne, Australia.

Provost, A. \& VILlemot, J. M. (1959). Recherches immunologiques sur la péripneumonie IV. A propos du diagnostic de laboratoire de la pleuropneumonie contagieuse caprine. Revue Elev. Méd. vét. Pays trop. 12, I I.

Provost, A., Villemot, J. M. \& Queval, R. (1964). Essais de vaccination contre la péripneumonie a l'aide de microorganisms du genre de Mycoplasma autre que Mycoplasma mycoides. Bull. epizoot. Dis. Afr. 12, 153. 
Provost, A., Villemot, J. M., Queval, R. \& Borredon, C. (1964). Recherches immunologiques sur la péripneumonie. IX. Donnes nouvelles sur les relations antigéniques de Mycoplasma mycoides. avec d'autre Mycoplasmataceae. Revue Elev. Méd. vét. Pays trop. I7, 23.

Richardson, G. M. (194I). Preservation of liquid complement serum. Lancet ii, 696.

SHIFrINE, M. \& GourLAY, R. N. (1967). Serological relationships between Mycoplasma mycoides and other bacteria. Ann. N.Y. Acad. Sci. 143, 317.

StoKes, E. J. (1955). Human infection with pleuropneumonia-like organisms. Lancet i, 276.

TURNER, A. W. (1962). Circulating Mycoplasma mycoides antigen as a cause of loss of agglutination and complement-fixation reactivity during acute pleuropneumonia. Aust. vet. J. 38, 40 I.

Villemot, J. M. \& Provost, A. (1959a). Recherches immunologique sur la péripneumonie. III. Isolement an Tchad de PPLO génitaux d'origine bovine. Revue Élev. Méd. vét. Pays trop. 12, 5.

Villemot, J. M. \& Provost, A. (1959b). Recherches immunologiques sur la péripneumonie. V. Relations antigenique entre Mycoplasma mycoides var. mycoides, M. mycoides var. capri et d'autre micro-organisms du genre Mycoplasma (souches génitales bovines et humaines). Revue Élev. Méd. vét. Pays trop. 12, 251. 